\title{
Persistent Joint Pain Following Arthropod Virus Infections
}

\author{
Karol Suchowiecki ${ }^{1}$ (1) - St. Patrick Reid ${ }^{2} \cdot$ Gary L. Simon $^{1} \cdot$ Gary S. Firestein $^{3} \cdot$ Aileen Chang $^{1}$ \\ Accepted: 20 January 2021 / Published online: 13 April 2021 \\ (C) The Author(s), under exclusive licence to Springer Science+Business Media, LLC part of Springer Nature 2021
}

\begin{abstract}
Purpose of Review Persistent joint pain is a common manifestation of arthropod-borne viral infections and can cause long-term disability. We review the epidemiology, pathophysiology, diagnosis, and management of arthritogenic alphavirus infection.

Recent findings The global re-emergence of alphaviral outbreaks has led to an increase in virus-induced arthralgia and arthritis. Alphaviruses, including Chikungunya, O'nyong'nyong, Sindbis, Barmah Forest, Ross River, and Mayaro viruses, are associated with acute and/or chronic rheumatic symptoms. Identification of Mxra8 as a viral entry receptor in the alphaviral replication pathway creates opportunities for treatment and prevention. Recent evidence suggesting virus does not persist in synovial fluid during chronic chikungunya infection indicates that immunomodulators may be given safely.

Summary The etiology of persistent joint pain after alphavirus infection is still poorly understood. New diagnostic tools along and evidence-based treatment could significantly improve morbidity and long-term disability.
\end{abstract}

Keywords Alphavirus $\cdot$ Arthritis $\cdot$ Chikungunya $\cdot$ Ross River $\cdot$ Mayaro $\cdot$ Sindbis

\section{Introduction}

Arthropod-borne viruses are a major cause of virally induced joint pain worldwide. Usually, joint pain occurs during acute infection and is self-limited, such as in Flavivirus infections such as Dengue [1]. However, arthropod-borne viruses from the genus Alphavirus can cause chronic and persistent

This article is part of the Topical Collection on Chronic Pain

Aileen Chang

chang@email.gwu.edu

Karol Suchowiecki

karol16688@gwu.edu

St. Patrick Reid

Patrick.reid@unmc.edu

Gary L. Simon

gsimon@mfa.gwu.edu

Gary S. Firestein

gfirestein@health.ucsd.edu

1 Department of Medicine, George Washington University, 2150 Pennsylvania Ave Suite 5-416, Washington, DC 20037, USA

2 Department of Pathology and Microbiology, 985900 Nebraska Medical Center, Omaha, NE 68198-5900, USA

3 UC San Diego Health Sciences, 9500 Gilman Drive \#0602, La Jolla, CA 92093, USA arthralgia and arthritis following infection $[2,3]$. In particular, old world alphaviruses, including Chikungunya virus (CHIKV), O'nyong'nyong virus (ONNV), Sindbis virus (SINV), Barmah Forest virus (BFH), Ross River virus (RRV), and new world alphavirus, Mayaro virus (MAYV), can cause persistent joint pain [4]. Factors like climate change, travel, globalization, aging, and urbanization have increased the number of arthropod-borne outbreaks in the last quarter century [5]. CHIKV is the best-studied Alphavirus and causes debilitating and long-term chronic joint disease. This review will analyze current knowledge about the epidemiology, pathophysiology, diagnosis, treatment, and management of arthropod infections that cause persistent joint pain.

\section{Epidemiology of Alphavirus Infection}

Mosquitos such as Aedes aegypti, Aedes albopictus, Aedes vigilax, and Culex annulirostris are the main vectors for alphavirus transmission; however, other vectors including birds, kangaroos, and wallabies also play a role [6]. Alphaviruses are maintained through the sylvatic transmission cycle which consists of viral transmission from mosquitos to animals, with vertebrates often serving as the amplifying hosts [6-8]. During human outbreaks, transmission occurs in an urban cycle where humans serve as hosts and mosquitos are 
vectors that infect other humans [4]. For example, during a SINV outbreak, Culex mosquitos infect humans who serve as the hosts for the virus [9]. Between human outbreaks, the viral transmission is dominated by the sylvatic cycle as demonstrated by RRV where marsupials serve as hosts and decreased human infection occurs [10]. These transmission and host patterns are held by all alphaviruses varying only in host and vector species.

\section{Chikungunya Virus}

CHIKV was first isolated from a febrile individual in what is now Tanzania in 1952 [11]. Several CHIKV outbreaks occurred in Africa and Asia between 1960 and 1980 [12]. After 1980, the next major outbreak occurred in 2004 on Lamu Island, Kenya, where $70 \%$ of the island's population was infected [12]. The virus then spread to other nearby islands, including the La Réunion island, due to the migration of humans and Aedes mosquitos. Genetic analysis confirmed a mutation at residue 226 of the membrane fusion glycoprotein E1 (E1-A226 V) in the virus during September 2005 which increased replication rates in Aedes albopictus mosquitos that were often co-infected with Semliki forest virus $[12,13]$. This mutation which enabled wider distribution of transmission drove the 2005-2006 CHIKV outbreak [13]. In December 2013, the first reported case of CHIKV in the Americas occurred in Saint Martin [14]. The virus eventually spread to the mainland of the Americas through human and mosquito travel. In 2014, there were reports of CHIKV and DENV coinfection in a traveler returning to Portugal from Angola [15]. CHIKV is now a global disease and infections have been reported in all continents except Antarctica [16]. In 2019, the CDC reported 171 travel associated CHIKV cases in the USA and 2 locally transmitted cases in Puerto Rico [17]. Puerto Rico experienced the highest local transmission rate in 2014 when 4242 cases were reported [17]. In the last 6 years, local transmission of CHIKV in a US state was recorded in 2015 with one case in Texas, and in 2014 with 14 cases in Florida [17]. Recently, there have been outbreaks in the Americas, Caribbean, Sudan, Yemen, Cambodia, and Chad [18]. Continued CHIKV transmission fuels the imperative to develop a reliable vaccine to prevent outbreaks and treatments to relieve chronic CHIKV arthritic disease.

\section{O'nyong'nyong virus}

ONNV is an arbovirus that is transmitted by Anopheles mosquitos and was first isolated in 1959 in Uganda during an epidemic that involved 2 million patients [19-21]. The countries affected by the 1959-1963 epidemic were Kenya, Tanzania, Zaire, Malawi, Mozambique, and Uganda [22]. There were no signs of ONNV until the next major epidemic in 1996 which began in Southern Uganda and spread to the districts of Masaka and Mbarra [23]. Molecular studies showed that the ONNV genetic sequence shares a high degree of homology with the 1959 ONNV isolate [20]. In the areas that were affected, the infection rate was $45 \%$ [20]. A reportedly smaller outbreak took place in 2002 in Central Uganda, although surveillance and testing were very limited [24]. In 2003, in a Liberian refugee camp 31 refugees had ONNV fever symptoms; due to the political nature of the situation, further investigation into this outbreak was not done [25, 26]. ONNV has not spread outside of its geographic origins, and as a result, extensive surveillance has not been done and the degree of viral penetrance into the population is uncertain. Humans are the only known vertebrate reservoir which may explain the sporadic nature of ONNV outbreaks historically [27].

\section{Sindbis Virus}

SINV is an arthritogenic alphavirus that is transmitted by mosquitoes and is found in Africa, Europe, Australia, and Asia $[28,29]$. SINV was first isolated in Cairo, Egypt, from a Culex mosquito during an outbreak of a febrile illness that also caused rash and arthritis [30]. Since this discovery, outbreaks of SINV on the African continent have only occurred in South Africa [31]. The two largest outbreaks in South Africa occurred in 1963 and 1974 and coincided with detection of SINV in Northern Europe [31]. SINV likely spread from South Africa to Sweden via migratory birds, although some investigators believe that the virus spread from Central Africa to Sweden in a singular isolated event [32, 33]. From Sweden, SINV then spread to Finland, Russia, and Germany [32]. The first isolated SINV case in Germany occurred in 2009 in Culex mosquito species [34]. The endemic SINV areas in Europe, primarily Central Sweden, report about 3 human cases of SINV annually during non-outbreak years [35]. In 2013, Sweden experienced an outbreak outside of the endemic area where 50 patients had confirmed SINV IgG [35]. After a 6-8month follow-up, $39 \%$ of these patients still had joint pain as a result of SINV infection [35]. Since 2013, no major SINV outbreaks have been reported.

\section{Mayaro Virus}

MAYV is transmitted by Haemagogus, Culex, Mansonia, Aedes, Psorophora, Sabethes, and Coquillettidia mosquitos $[36,37]$. It is the only known arthritogenic new world alphavirus [38]. MAYV was first isolated from five workers in Mayaro, Trinidad, in 1954 [39, 40]. It spread to several other countries in Central America and the northern portions of South America [40-42]. One of the largest outbreaks occurred in Venezuela in 2010 that involved 77 cases [38]. In 2015, the virus was detected in a young patient in Haiti who lived in a non-forest area [41, 43, 44]. Cases have also been 
reported in North America and Europe mostly likely due to international travel [44]. From the discovery of MAYV in 1954 to 2019, Brazil has had 495 cases, Peru has had 230 cases, Venezuela has had 81 cases, and Bolivia has had 61 cases. Other countries in the region have each reported less than 6 cases $[45,46]$.

\section{Barmah Forest Virus}

$\mathrm{BFV}$ is an alphavirus that is most commonly found in Australia. BFV was initially isolated in 1974 from Culex annulirostris mosquitos that were collected in the Barmah Forest in Victoria, Australia [47]. The first human cases were reported in Australia in 1986 [48]. Traditionally, BFV was thought to the only endemic to Australia, but the virus has been found in Papua New Guinea. A 5-year-old child from Papua New Guinea with no history of international travel was found to have BFV in 2014 suggesting possible endemic spread [49]. In the past 10 years, about 1600 annual cases of BFV have been reported in Australia [50]. There have been several larger outbreaks reported in Australia in 1992, 1993, 1994, 1995, and 2002 [47]. BFV may have an avian or bat host and is transmitted by mosquitoes to humans [48]. BFV is often confused with Ross River virus as both have very similar symptoms and are found in similar regions in Australia. Like other mosquito-borne diseases, climate change may have an impact on transmission and outbreak timing. Having been only isolated in Australia and Papua New Guinea thus far, BFV is one of the least studied alphaviruses; however, it should not be underestimated. It has the potential for widespread distribution similar to Chikungunya virus.

\section{Ross River Virus}

Ross River virus (RRV) was discovered in 1959 from an Aedes vigilax mosquito in Queensland, Australia [7]. RRV is very similar to $\mathrm{BFV}$; however, it has a much greater impact on health in Australia than BFV. RRV has an annual incidence rate of greater than 40 cases per 100,000 persons per year or about 5000 cases annually $[51,52]$. Similar to BFV, RRV is also endemic in Papua New Guinea and some other Pacific islands [51]. There was an epidemic of RRV in 1979-1980 that affected many Pacific islands including Fiji, Tonga, Samoa, Cook Islands, and New Caledonia [53]. This outbreak was characterized by a new strain of RRV that had been identified years earlier in Australia and resulted in humanmosquito spread with little evidence of amplifying vertebrae host involvement [53]. Since the spread of CHIKV to Latin America, there is speculation about whether viruses like RRV can spread globally due to changing climate and global travel. Australia has also reported an increase in annual RRV cases in endemic areas and has also documented spread of RRV into novel parts of Australia [54, 55].

\section{Pathophysiology}

All of the alphaviruses share a similar mechanism of infection and replication. Almost all of the known pathways of infection and replication are based on CHIKV, which, as a result of its prevalence has been very heavily studied. The first phase of infection is the pre-acute phase in which the mosquito bite transfers the virus into human tissue. This bite triggers an immediate inflammatory response with increased capillary permeability and release of chemokines CXCL1 and CXCL2 by tissue macrophages and mast cells that attract neutrophils to the site of infection [56, 57•]. The neutrophils produce reactive oxygen species and form neutrophil extracellular traps (NETs) to decrease and trap the virus immediately after infection [57॰]. Nevertheless, the virus can enter permissive cells at the infection site as well as distant sites due to hematogenous spread. The CHIKV incubation period is about 2-4 days during which the viral load can reach $10^{8}$ particles per milliliter of blood [58]. CHIKV enters and replicates in a variety of cell lineages, including fibroblasts and macrophages at the infection site. It can then travel systemically through the lymph nodes, spleen, liver, muscles, and joints [59-62]. MAYV also targets macrophages in order to replicate [63].

Although the alphavirus life cycle (Fig. 1) is not fully understood in all arthritogenic alphaviruses, the CHIKV life cycle can provide insight into the general alphavirus replication mechanism. First, the alphavirus enters the target cell through clathrin-mediated endocytosis; however, some studies have shown that entry may also occur through a clathrin independent pathway or via micropinocytosis [64]. Mxr8 has been implicated as an important viral entry receptor for CHIKV, RRV, MAYV, and ONNV; it consists of two immunoglobulin-like domains and its expression was found to be necessary for efficient infection of fibroblasts, skeletal muscle cells, and chondrocytes $[65 \bullet, 66 \bullet, 67]$. Mxra8 is not an exclusive receptor because residual CHIKV infection was detected in Mxra8-deficient mice [64]. Treatment of mice with anti-Mxra8 antibody reduced the number of cells in the chronic phase of infection and lowered levels of chronic viral RNA [68]. Other receptors that assist in viral entry include dendritic cell-specific ICAM3 grabbing non-integrin 1 (DC-SIGN), liver and lymph node SIGN. In addition, laminin, heparan sulfate, keratan sulfate, chondroitin sulfate, dermatan sulfate, and other factors have been proposed [58, 69, 70]. In RRV infection, collagen $\alpha 1 \beta 1$ integrin serves as an important receptor. Inhibition of $\alpha 1 \beta 1$ integrin by type IV collagen and anti- $\alpha 1 \beta 1$ antibodies inhibited RRV infection in mice [64]. The alphaviral glycoprotein E2 mediates fusion between the virus and host cell receptors which is followed by receptor mediated endocytosis.

In the endosome, the acidic environment leads to the fusion of alphaviral glycoprotein E1 to the endosomal membrane resulting in the release of viral RNA into the cytoplasm of the 


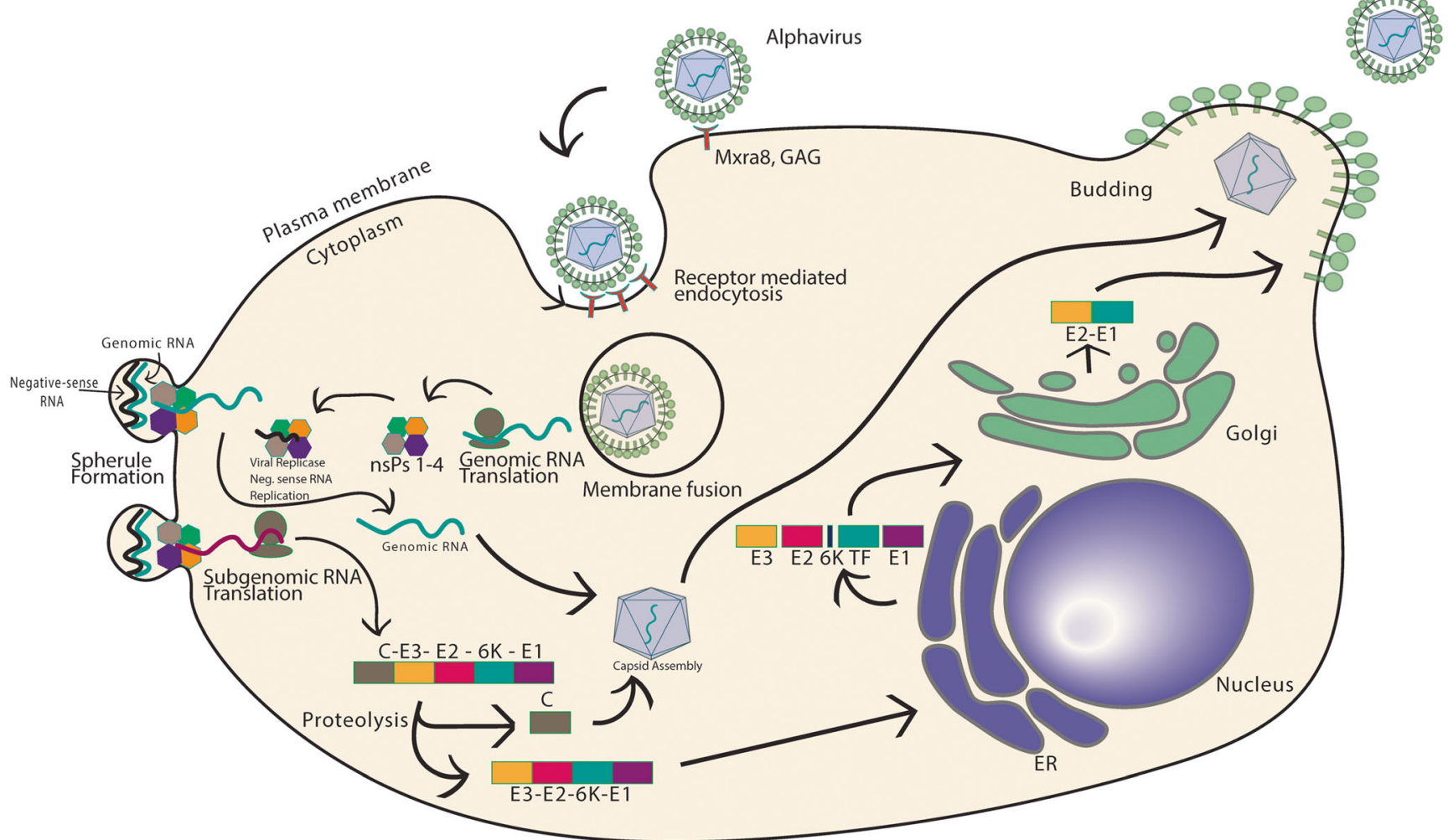

Fig. 1 Mechanism of alphavirus replication. Alphaviruses attach to the host cell through attachment of viral E2 glycoprotein to cell surface receptors such as Mxra8 and GAGs. After endocytosis, the acidic endosome triggers membrane fusion of $\mathrm{E} 1$ glycoprotein resulting in the release of viral contents into the cell. The genomic RNA is translated into four non-structural proteins which go on to form a replicase that synthesizes negative-sense RNA. The non-structural proteins can form spherules where positive-sense and subgenomic RNA synthesis occurs based on the negative-sense template. The subgenomic RNA is translated to form the C-E3-E2-6K-TF-E1 polyprotein which is cleaved and trafficked to the endoplasmic reticulum and Golgi apparatus where post-translational modification results in the final individual structural proteins of the virus cell [70]. The viral positive-sense RNA is translated to polyprotein P1234 directly in the cytosol which, after cleavage, forms non-structural proteins (nsP) 1, 2, 3, and 4 (Fig. 1) [58, 70]. The four nsPs and genomic RNA assemble at the plasma membrane into viral replication compartments (spherules) that synthesize antigenomic, genomic, and subgenomic RNA (Fig. 1) [70]. The spherule-synthesized subgenomic RNA is translated into capsid protein which internalizes the genomic RNA to form icosahedral nucleocapsids (Fig. 1) [58, 70]. Simultaneously, E3-E2-6K/TF-E1 polyprotein, synthesized from subgenomic RNA, enters the endoplasmic reticulum post-transcriptionally and is secreted through the ER-Golgi pathway where it is integrated into the plasma membrane (Fig. 1) [70]. The genomic RNA nucleocapsid then buds off at the site where E2- and E1-secreted proteins are located to form a mature virion (Fig. 1) [58, 70, 71].

After alphaviral infection, there is both an acute and chronic stage, resulting in polyarthralgia which is often debilitating to patients. There is widespread viral dissemination through the circulatory and lymphatic systems to multiple organs and joints after which multiple immune effector cells infiltrate the site of infection leading to the production of pro-inflammatory cytokines which results in severe polyarthralgia (Table 1) [56, 69, 72]. These cytokines persist in the infected tissues even during the recovery phase which may indicate that they play a role in leading to chronic viral arthritogenic arthritis [91]. A type 1 interferon response also occurs in SINV, RRV, and CHIKV [35].

After infection, neutralizing antibodies are usually detected 4-7 days after the onset of symptoms and contribute to alphaviral clearance from the blood [56]. CD8+ T cells are vital to RRV clearance from infected muscle tissues and important in mediation of vaccine-induced protection against CHIKV in mice $[92,93]$. The ultimate outcome of the infection is mediated by macrophage polarization and phenotype switching from pro-inflammatory (M1) to anti-inflammatory (M2) [56]. Interestingly, arginase 1 is an M2 macrophage enzyme that was associated with decreased tissue damage and enhanced RRV clearance in mice [94, 95•]. The exact mechanistic differences by which certain patients are able to clear infection without developing chronic arthritis while others suffer from debilitating joint pain are poorly understood. 
Table 1 Elevated serum cytokines and chemokines in chronic CHIKV-associated arthralgia and arthritis

\begin{tabular}{|c|c|}
\hline Cytokine/chemokine & Function \\
\hline IFN- $\alpha[72-75]$ & $\begin{array}{l}\text { Promotion of antiviral state, limits CHIKV replication and dissemination } \\
\text { NK cell activation }\end{array}$ \\
\hline IFN- $\gamma[72,76-78]$ & $\begin{array}{l}\text { Macrophage and B cell activation, Th1 differentiation, increased MHC } 1 \\
\text { and MHC II }\end{array}$ \\
\hline TNF $[72,79,80]$ & Pro-inflammatory signaling, neutrophil activation \\
\hline IL-1 $\beta[72,81,82]$ & Pro-inflammatory signaling, Th17 differentiation \\
\hline IL-6 [72, 77, 81, 83-86] & $\begin{array}{l}\text { Th17 differentiation, } \mathrm{T} \text { reg inhibition, synthesis of acute phase proteins, } \\
\text { stimulation of antibody production }\end{array}$ \\
\hline IL-8 $[72,77,86,87]$ & Neutrophil chemotaxis \\
\hline IL-10 $[72,81,88,89]$ & $\begin{array}{l}\text { Suppresses expression of pro-inflammatory cytokines, inhibition of } \\
\text { neutrophil recruitment }\end{array}$ \\
\hline IL-12 [72, 90] & Th1 differentiation, IFN $\gamma$ synthesis in NK and T cells \\
\hline CCL2 $[56,72,86]$ & Recruits $\mathrm{T}$ cells, monocytes, and dendritic cells to sites of inflammation \\
\hline
\end{tabular}

The chronic phase of alphaviral arthritis seems to be associated with a pro-inflammatory state $[56,69,72]$. A primary cellular mediator of chronic CHIKV-induced joint swelling is IFN $\gamma$ secreting Th1 CD4+ T cells that attract phagocytic cells to the site of infection [96]. There are two main hypotheses as to why persistent arthritis occurs in patients with alphaviral infection. First, the persistence of viral RNA or proteins in the joint and muscle tissues or macrophages may cause the persistent arthritis [97]. Second, there may be persistent immune activation similar to rheumatoid arthritis (RA) which leads to chronic join pain [97]. Although it is possible that CHIKV resides in macrophages that upon activation cause relapsing-remitting arthritic symptoms $[98,99 \bullet \bullet]$, the bulk of the evidence suggests that the chronic arthritic condition is due to persistent immune activation. One study did find CHIKV RNA and proteins in one patient 18 months post-infection [90]. However, there is a significant reduction in detectable viral RNA or viral particles in the chronic phase after the initial acute infection [56]. Synovial fluid samples from 38 Colombian patients who reported chronic arthritis 22 months post-infection did not reveal detectable CHIKV transcripts or viral proteins [100]. The lack of viral RNA and proteins suggests that the underlying cause of pain or synovitis years post-infection is more likely persistent immune activation [99••]. CHIKV arthritis persists in some patients 3 years post-infection, in many cases as relapsing and remitting [101••]. This may suggest that during the chronic phase, there is an intensity variation in the inflammatory response causing relapsing-remitting symptoms frequently reported in response to exercise or infection [101••].

Other alphaviruses, such as RRV, ONNV, SINV, and MAYV, can induce similar rheumatic-like manifestations in patients with persistent arthritis. A sequence alignment of viral proteins from arthritogenic alphaviruses showed that there are conserved regions in the protein structure that can activate $\mathrm{T}$ cells similar to endogenous proteins that are implicated in RA [102]. Another study demonstrated that patients with previous
RA who became newly infected with CHIKV developed more RA symptoms which may suggest that both CHIKV arthritis and RA function through similar mechanisms [103]. These findings suggest that the origin of chronic joint pain from alphaviral infection is mediated through an autoimmune response to conserved regions of the viral proteins.

\section{Diagnosis}

Alphaviral infections have an incubation period that ranges from 1-12 days varying between each specific alphavirus [96]. Symptoms are generally similar among alphaviral infections and include fever, macular rash, facial edema, edema of the extremities, pruritus, myalgia, arthralgia, periorbital pain, headache, lymphadenopathy, and minor bleeding [62]. Symptoms overlap among the alphaviruses, so serology testing or RT-PCR is important for the diagnosis [69]. The latter is perhaps the most sensitive method for detection of virus [4, $104,105]$. A fourfold increase of virus-specific IgM antibodies at least 3 weeks apart can be used if RT-PCR is not available [69]. If the diagnosis cannot be made in the acute phase, serological testing can still be used to detect virus-specific IgG and IgM levels, because they persist for months to years postinfection [69]. CHIKV IgM levels can persist or even increase with disease activity during untreated chronic infection [106]. However, routine serologic testing is often complicated by cross-reactivity among alphaviruses.

If symptoms persist beyond the acute phase of infection, the common finding among the arthritogenic alphaviral infections is persistent joint pain. In addition to serological testing, disease activity measures should be used to evaluate the severity and activity of ongoing arthritis. Methods used to assess rheumatoid arthritis are often applied to other diseases, such as CHIKV arthritis [107]. CHIKV frequently involves the small joints of the 
hands and feet and as such some instruments may underestimate that the severity of the arthritis may be due to lack of inclusion of these joints. In contrast to RA, swollen joints in CHIKV arthritis are poor predictors of outcomes while joint pain and stiffness may be independently associated with disability and quality of life assessments. Musculoskeletal stiffness during CHIKV infection is often not associated with arthralgia; therefore, inclusion of stiffness as a separate parameter may provide a more accurate assessment of disease severity in CHIKV infection [108].

\section{Treatment and Management}

There is no specific antiviral treatment or approved vaccine for any of the arthritogenic alphaviruses, although there are numerous proposed treatments with putative efficacy (Table 2). In the acute phase of infection, acetaminophen for 14 days is appropriate [62]. The use of NSAIDS or aspirin should be avoided until a specific alphaviral infection is confirmed because of bleeding complications associated with dengue fever which is clinically indistinguishable from alphaviral infection [62]. France and Brazil have established more specific guidelines for chronic chikungunya arthritis (CCA) $[109,110] .12$ weeks post-infection, these guidelines state that disease modifying antirheumatic drugs (DMARDs) such as methotrexate (MTX) can be used [111]. However, there are no adequately powered randomized clinical trials showing that MTX improves outcomes [112]. Some studies support the use of MTX treatment in CCA with reporting resolution of joint symptoms, although there are potential concerns about the safety of MTX in infected patients [113•]. Chloroquine and hydroxychloroquine have been tried as treatments for CHIKV arthritis but there has been no evidence of therapeutic benefit in clinical trials $[114,115]$. Corticosteroids are generally not recommended in acute infection due to the immunosuppressive effect and other adverse effects even

Table 2 Prospective alphaviral arthritis therapies

Prospective alphaviral arthritis therapies

\begin{tabular}{|c|c|c|c|}
\hline Therapy & Mechanism of action & Effect & Alphavirus known to effect \\
\hline NSAIDs [111, 119-123] & Inhibition of cyclooxygenase & $\begin{array}{l}\text { Decreased prostaglandins, prostacyclins } \\
\text { leading to less inflammation }\end{array}$ & $\begin{array}{l}\text { Acute symptom-based } \\
\text { coverage of all } \\
\text { alphaviruses }\end{array}$ \\
\hline $\begin{array}{l}\text { Steroids (Prednisone) } \\
{[116,124-126]}\end{array}$ & $\begin{array}{l}\text { Suppresses leukocyte migration, } \\
\text { reversal } \\
\text { of vascular permeability }\end{array}$ & $\begin{array}{l}\text { Multiple immunomodulatory and } \\
\text { immunosuppressive effects, not recommended } \\
\text { for alphaviral arthritis due to risk of infection } \\
\text { exacerbation }\end{array}$ & CHIKV, RRV \\
\hline $\begin{array}{l}\text { Methotrexate } \\
\quad[106,112,113 \cdot, 118 \\
125,127]\end{array}$ & $\begin{array}{l}\text { Inhibits dihydrofolate reductase, } \\
\text { increase } \\
\text { in adenosine release, decreased } \\
\text { reduction } \\
\text { of } \mathrm{BH} 2 \text { to BH4, inhibits NFKB } \\
\text { activation }\end{array}$ & $\begin{array}{l}\text { Suppression of pro-inflammatory effects of T } \\
\text { cells, macrophages, fibroblast synoviocytes, } \\
\text { and endothelial cells }\end{array}$ & CHIKV, RRV \\
\hline $\begin{array}{l}\text { Hydroxychloroquine } \\
{[111,114,116,} \\
128-131]\end{array}$ & $\begin{array}{l}\text { Disrupts lysosomal/endosomal pH, } \\
\text { inhibition } \\
\text { of MHC II presentation, inhibition of } \\
\text { TLR signaling, inhibition of cGAMP } \\
\text { synthase }\end{array}$ & $\begin{array}{l}\text { Reduction of pro-inflammatory cytokines, } \\
\text { decreased T cell activation, no evidence } \\
\text { of therapeutic benefit }\end{array}$ & CHIKV, RRV \\
\hline $\begin{array}{l}\text { Sulfasalazine } \\
\quad[109,111,117,118]\end{array}$ & $\begin{array}{l}\text { Inhibits NF-kB, RANKL suppression, } \\
\text { osteoprotegerin stimulation }\end{array}$ & $\begin{array}{l}\text { Reduction of pro-inflammatory cytokines, } \\
\text { decreased T cell activation, decreased } \\
\text { tissue damage }\end{array}$ & CHIKV, RRV \\
\hline $\begin{array}{l}\text { Pentosan Polysulfate } \\
\quad[132-134]\end{array}$ & $\begin{array}{l}\text { GAG with heparin-like structure, } \\
\text { upregulation of IL-10, } \\
\text { downregulation } \\
\text { of IL-6 }\end{array}$ & Anti-inflammatory, enhancement of tissue repair & CHIKV, RRV \\
\hline $\begin{array}{l}\text { TNF inhibitors } \\
{[103,135,136]}\end{array}$ & $\begin{array}{l}\text { Binds and inhibits TNF } \\
\text { pro-inflammatory cascade signaling }\end{array}$ & $\begin{array}{l}\text { Reduction of pro-inflammatory effects of } \\
\text { TNF signaling, decrease in IL- } 1 \text { and IL- } 6\end{array}$ & CHIKV \\
\hline Fingolimod $[137,138 \bullet]$ & $\begin{array}{l}\text { Modulates of sphingosine 1-phosphate } \\
\text { receptor }\end{array}$ & Prevents T cell escape from lymph nodes & CHIKV \\
\hline Abatacept $[137,139 \bullet]$ & Binds to CD80/CD86 on APC's & Inhibits $T$ cell activation & CHIKV \\
\hline Bindarit $[140,141]$ & $\begin{array}{l}\text { Inhibits MCP-1/CCL2, CCL7, } \\
\text { CCL8, and IL-12 }\end{array}$ & $\begin{array}{l}\text { Decreases joint inflammation and } \\
\text { osteoclastogenesis }\end{array}$ & CHIKV, RRV \\
\hline $\begin{array}{l}\text { Tofacitinib } \\
\qquad[103,142,143]\end{array}$ & Inhibits JAK & $\begin{array}{l}\text { Inhibits pro-inflammatory signaling cascade, } \\
\text { decreased T cell activation }\end{array}$ & CHIKV \\
\hline
\end{tabular}


though there is evidence of potential therapeutic benefit when in combination with NSAIDs especially in chronic infection $[111,116]$. Lastly, sulfasalazine treatment might have therapeutic benefit especially when combined with methotrexate $[117,118]$. It is necessary to further test the French and Brazilian recommended therapies in randomized controlled trials to know which treatments are effective.

Antivirals, antibody therapies, and vaccines are being tested for potential efficacy against arthritogenic alphaviruses. The Mxra8 receptor is a target for using monoclonal antibodies. Mxra8 was inhibited by RRV-12 and CHIKV-70 human antibodies [144]. Specifically, RRV-12 reduced clinical disease in immunocompetent RRV and MAYV mouse models [144]. Another potential therapeutic, Bindarit, a MCP-1 inhibitor, has shown activity against monocyte chemoattractant proteins MCP-1, MCP-2, and MCP-3 resulting in decreased MCPdriven monocyte infiltration into infected joints [140]. Bindarit treatment in a mouse model decreased joint swelling compared with the control $[140,145]$. Abatacept, a CTLA4-Ig that inhibits $\mathrm{T}$ cell activation, decreased foot swelling on day 7 of CHIKV infection in mice. It had greater effectiveness when combined with anti-CHIKV monoclonal antibodies which eliminated viral particles and reduced viral RNA levels in joints $\left[137,139{ }^{\bullet}\right.$. Another approach that has had success in mouse models involved the use of fingolimod, a sphingospine-1phosphate receptor modulator, which prevented $\mathrm{T}$ cell escape from lymphoid organs, thus reducing joint inflammation [137, 138•]. Another potential target for therapeutics is microRNAs which have shown to positively and negatively impact both osteoclastogenesis and osteoblastogenesis [146, 147]. Bone remodeling is an important part of CHIKV infection and a major cause of morbidity and thus is a promising area of research.

In addition to potential therapeutics, there is an effort to develop a CHIKV vaccine. The most recent phase 2 vaccine trial of a CHIKV virus-like particle vaccine resulted in a lasting immune response through 72 weeks post-vaccination [148]. Another vaccine candidate, MV-CHIK, completed its phase 2 trial and induced neutralizing antibodies in $93 \%$ of individuals in the high-dose group after a single immunization [149]. Additional trials using live attenuated viruses are in progress [150]. Other vaccine candidates include an mRNA vaccine encoding for CHIKV antigenic proteins, live attenuated virus vaccine, viral vectored vaccine, and a virus-like particle vaccine all of which are in development [151•].

\section{Conclusion}

Although global travel has decreased in 2020 due to the COVID-19 pandemic, arthropod-borne viruses continue to cause outbreaks. Climate change, migration and future travel will keep on increasing the regions that vectors populate. A complete understanding of alphaviral pathophysiology will undoubtedly lead to novel therapeutic targets. There is also hope for an affordable vaccine in the coming future which will be key to preventing large-scale outbreaks. Currently, the use of mosquito deterrent strategies and the potential role some of the agents listed above may be the best methods for prevention and treatment of persistent joint pain following arthropod viral infections.

Acknowledgements Research reported in this publication was supported by the National Institute Of Arthritis And Musculoskeletal And Skin Diseases of the National Institutes of Health under Award Number K23AR076505. The content is solely the responsibility of the authors and does not necessarily represent the official views of the National Institutes of Health.

\section{Declarations}

Conflict of Interest The authors declare that they have no conflict of interest.

Ethics Approval and Consent to Participate This article does not contain any studies with human or animal subjects performed by any of the authors.

\section{References}

Papers of particular interest, published recently, have been highlighted as:

- Of importance

•- Of major importance

1. Muller DA, Depelsenaire ACI, Young PR. Clinical and laboratory diagnosis of dengue virus infection. J Infect Dis. 2017;215:S8995. https://doi.org/10.1093/infdis/jiw649.

2. Burt FJ, Chen W, Miner JJ, Lenschow DJ, Merits A, Schnettler E, et al. Chikungunya virus: an update on the biology and pathogenesis of this emerging pathogen. Lancet Infect Dis. 2017;17:e10717. https://doi.org/10.1016/S1473-3099(16)30385-1.

3. Zaid A, Burt FJ, Liu X, et al. Arthritogenic alphaviruses: epidemiological and clinical perspective on emerging arboviruses. Lancet Infect Dis. 2020. https://doi.org/10.1016/S1473-3099(20) 30491-6.

4. Wesula Olivia L, Obanda V, Bucht G, Mosomtai G, Otieno V, Ahlm C, et al. Global emergence of Alphaviruses that cause arthritis in humans. Infect Ecol Epidemiol. 2015;5:29853. https:// doi.org/10.3402/iee.v5.29853.

5. Trovato M, Sartorius R, D'Apice L, Manco R, de Berardinis P. Viral emerging diseases: challenges in developing vaccination strategies. Front Immunol. 2020;11:2130. https://doi.org/10. 3389/fimmu.2020.02130.

6. Lim E, Lee W, Madzokere E, Herrero L. Mosquitoes as suitable vectors for alphaviruses. Viruses. 2018;10:84. https://doi.org/10. 3390/v10020084.

7. Sinclair JB, Asgari S. Ross River virus provokes differentially expressed microRNA and RNA interference responses in Aedes aegypti mosquitoes. Viruses. 2020;12:695. https://doi.org/10. 3390/v12070695. 
8. Earnest JT, Basore K, Roy V, Bailey AL, Wang D, Alter G, et al. Neutralizing antibodies against Mayaro virus require $\mathrm{Fc}$ effector functions for protective activity. J Exp Med. 2019;216:2282-301. https://doi.org/10.1084/jem.20190736.

9. Lundström JO, Hesson JC, Schäfer ML, Östman Ö, Semmler T, Bekaert M, et al. Sindbis virus polyarthritis outbreak signalled by virus prevalence in the mosquito vectors. PLoS Negl Trop Dis. 2019;13:1-20. https://doi.org/10.1371/journal.pntd.0007702.

10. Flies EJ, Lau CL, Carver S, Weinstein P. Another emerging mosquito-borne disease? Endemic Ross River virus transmission in the absence of marsupial reservoirs. Bioscience. 2018;68:288 93. https://doi.org/10.1093/biosci/biy011.

11. Ross RW. The Newala epidemic: III. The virus: isolation, pathogenic properties and relationship to the epidemic. J Hyg (Lond). 1956;54:177-91. https://doi.org/10.1017/S0022172400044442.

12. Zeller H, Van Bortel W, Sudre B. Chikungunya: its history in Africa and Asia and its spread to new regions in 2013-2014. J Infect Dis. 2016;214:S436-40. https://doi.org/10.1093/infdis/ jiw391.

13. Vazeille M, Moutailler S, Coudrier D, Rousseaux C, Khun H, Huerre M, et al. Two Chikungunya isolates from the outbreak of La Reunion (Indian Ocean) exhibit different patterns of infection in the mosquito, Aedes albopictus. PLoS One. 2007;2:e1168. https://doi.org/10.1371/journal.pone.0001168.

14. Sahadeo NSD, Allicock OM, De Salazar PM, et al. Understanding the evolution and spread of chikungunya virus in the Americas using complete genome sequences. Virus Evol. 2017;3:1-10. https://doi.org/10.1093/ve/vex010.

15. Parreira R, Centeno-Lima S, Lopes A, et al. Dengue virus serotype 4 and Chikungunya virus coinfection in a traveller returning from Luanda, Angola, January 2014. Eurosurveillance. 2014;19:6-9. https://doi.org/10.2807/1560-7917.ES2014.19.10.20730.

16. Silva JVJ, Ludwig-Begall LF, de Oliveira-Filho EF, et al. A scoping review of Chikungunya virus infection: epidemiology, clinical characteristics, viral co-circulation complications, and control. Acta Trop. 2018;188:213-24. https://doi.org/10.1016/j. actatropica.2018.09.003.

17. CDC. Chikungunya virus

18. WHO. Chikungunya

19. Tappe D, Kapaun A, Emmerich P, Campos RM, Cadar D, Günther S, et al. O'nyong-nyong virus infection imported to Europe from Kenya by a traveler. Emerg Infect Dis. 2014;20: 1766-7. https://doi.org/10.3201/eid2010.140823.

20. Sanders EJ, Rwaguma EB, Ssengooba FP, et al. O'nyong-nyong fever in South-Central Uganda, 1996-1997: description of the epidemic and results of a household-based seroprevalence survey. Infect Dis Ther. 1997;180(5):1436-43.

21. Nanfack Minkeu F, Vernick KD. A systematic review of the natural virome of Anopheles mosquitoes. Viruses. 2018;10:1-21. https://doi.org/10.3390/v10050222.

22. Lanciotti RS, Ludwig ML, Rwaguma EB, Lutwama JJ, Kram TM, Karabatsos N, et al. Emergence of epidemic O'nyong-nyong fever in uganda after a 35-year absence: genetic characterization of the virus. Virology. 1998;252:258-68. https://doi.org/10.1006/viro. 1998.9437.

23. Clements TL, Rossi CA, Irish AK, Kibuuka H, Eller LA, Robb ML, et al. Chikungunya and o'nyong-nyong viruses in Uganda: implications for diagnostics. Open Forum Infect Dis. 2019;6:1-7. https://doi.org/10.1093/ofid/ofz001

24. Vanlandingham DL, Hong C, Klingler K, et al. Differential infectivities of O'nyong-nyong and chikungunya virus isolates in Anopheles gambiae and Aedes aegypti mosquitoes. Am J Trop Med Hyg. 2005;72:616-21. https://doi.org/10.4269/ajtmh.2005. 72.616 .
25. Posey DL, O'Rourke T, Roehrig JT, et al. Short report: O'nyongnyong fever in West Africa. Am J Trop Med Hyg. 2005;73:32. https://doi.org/10.4269/ajtmh.2005.73.1.0730032.

26. Bessaud M, Peyrefitte CN, Pastorino BAM, Gravier P, Tock F, Boete F, et al. O'nyong-nyong virus. Chad Emerg Infect Dis. 2006;12:1248-50. https://doi.org/10.3201/eid1208.060199.

27. Powers AM, Brault AC, Tesh RB, Weaver SC. Re-emergence of chikungunya and o'nyong-nyong viruses: evidence for distinct geographical lineages and distant evolutionary relationships. J Gen Virol. 2000;81:471-9. https://doi.org/10.1099/0022-131781-2-471.

28. Kurkela S, Manni T, Myllynen J, Vaheri A, Vapalahti O. Clinical and laboratory manifestations of sindbis virus infection: prospective study, Finland, 2002-2003. J Infect Dis. 2005;191:1820-9. https://doi.org/10.1086/430007.

29. Bergqvist J, Forsman O, Larsson P, Näslund J, Lilja T, Engdahl C, et al. Detection and isolation of sindbis virus from mosquitoes captured during an outbreak in Sweden, 2013. Vector-Borne Zoonotic Dis. 2015;15:133-40. https://doi.org/10.1089/vbz. 2014.1717.

30. Taylor RM, Hurlbut HS, Work TH, Kingston JR, Frothingham TE. Sindbis virus: a newly recognized arthropod-transmitted virus 1. Am J Trop Med Hyg. 1955;4:844-62. https://doi.org/10.4269/ ajtmh.1955.4.844.

31. Adouchief S, Smura T, Sane J, Vapalahti O, Kurkela S. Sindbis virus as a human pathogen-epidemiology, clinical picture and pathogenesis. Rev Med Virol. 2016;26:221-41. https://doi.org/ 10.1002/rmv. 1876.

32. Ling J, Smura T, Lundström JO, Pettersson JHO, Sironen T, Vapalahti O, et al. Introduction and dispersal of Sindbis virus from Central Africa to Europe. J Virol. 2019;93:e00620-19. https://doi. org/10.1128/jvi.00620-19.

33. Lundström JO, Pfeffer M. Phylogeographic structure and evolutionary history of sindbis virus. Vector-Borne Zoonotic Dis. 2010;10:889-907. https://doi.org/10.1089/vbz.2009.0069.

34. Ziegler U, Fischer D, Eiden M, Reuschel M, Rinder M, Müller K, et al. Sindbis virus- a wild bird associated zoonotic arbovirus circulates in Germany. Vet Microbiol. 2019;239:108453. https:// doi.org/10.1016/j.vetmic.2019.108453.

35. Gylfe A, Ribers Å, Forsman O, Bucht G, Alenius GM, WållbergJonsson S, et al. Mosquitoborne sindbis virus infection and longterm illness. Emerg Infect Dis. 2018;24:1141-2. https://doi.org/ 10.3201/eid2406.170892.

36. Martins MM, Prata-Barbosa A, da Cunha AJLA. Arboviral diseases in pediatrics. J Pediatr. 2020;96:2-11. https://doi.org/10. 1016/j.jped.2019.08.005.

37. Pezzi L, Rodriguez-Morales AJ, Reusken CB, Ribeiro GS, LaBeaud AD, Lourenço-de-Oliveira R, et al. GloPID-R report on chikungunya, o'nyong-nyong and Mayaro virus, part 3: epidemiological distribution of Mayaro virus. Antivir Res. 2019;172: 104610. https://doi.org/10.1016/j.antiviral.2019.104610.

38. Auguste AJ, Liria J, Forrester NL, Giambalvo D, Moncada M, Long KC, et al. Evolutionary and ecological characterization of mayaro virus strains isolated during an outbreak, Venezuela, 2010. Emerg Infect Dis. 2015;21:1742-50. https://doi.org/10. 3201/eid2110.141660.

39. Anderson CR, Wattley GH, Ahin NW, Downs WG, Reese AA. Mayaro virus: a new human disease agent. Am J Trop Med Hyg. 1957;6:1012-6. https://doi.org/10.4269/ajtmh.1957.6.1012.

40. Camini FC, da Silva Caetano CC, Almeida LT, da Costa Guerra JF, de Mello Silva B, de Queiroz Silva S, et al. Oxidative stress in Mayaro virus infection. Virus Res. 2017;236:1-8. https://doi.org/ 10.1016/j.virusres.2017.04.017.

41. Arenívar C, Rodríguez Y, Rodríguez-Morales AJ, Anaya JM. Osteoarticular manifestations of Mayaro virus infection. Curr 
Opin Rheumatol. 2019;31:512-6. https://doi.org/10.1097/BOR. 0000000000000635.

42. Esposito DLA, da Fonseca BAL. Will Mayaro virus be responsible for the next outbreak of an arthropod-borne virus in Brazil? Braz J Infect Dis. 2017;21:540-4. https://doi.org/10.1016/j.bjid.2017.06.002.

43. Lorenz C, Freitas Ribeiro A, Chiaravalloti-Neto F. Mayaro virus distribution in South America. Acta Trop. 2019;198:105093. https://doi.org/10.1016/j.actatropica.2019.105093.

44. Acosta-Ampudia Y, Monsalve DM, Rodríguez Y, Pacheco Y, Anaya JM, Ramírez-Santana C. Mayaro: an emerging viral threat? Emerg Microbes Infect. 2018;7:1-11. https://doi.org/10.1038/ s41426-018-0163-5.

45. Ganjian N, Riviere-Cinnamond A. Mayaro virus in Latin America and the Caribbean. Rev Panam Salud Publica/Pan Am J Public Heal. 2020;44:1-11. https://doi.org/10.26633/RPSP.2020.14.

46. Diagne CT, Bengue M, Choumet V, Hamel R, Pompon J, Missé D. Mayaro virus pathogenesis and transmission mechanisms. Pathogens. 2020;9:738. https://doi.org/10.3390/ pathogens 9090738

47. Michie A, Ernst T, Chua IJ, et al. Phylogenetic and timescale analysis of Barmah Forest virus as inferred from genome sequence analysis. Viruses. 2020;12:732. https://doi.org/10.3390/ v12070732.

48. Ehlkes L, Eastwood K, Webb C, Durrheim D. Surveillance should be strengthened to improve epidemiological understandings of mosquito-borne Barmah Forest virus infection. West Pacific Surveill Response. 2012;3:63-8. https://doi.org/10.5365/wpsar. 2012.3.1.004

49. Caly L, Horwood PF, Vijaykrishna D, Lynch S, Greenhill AR, Pomat W, et al. Divergent Barmah Forest virus from Papua New Guinea. Emerg Infect Dis. 2019;25:2266-9. https://doi.org/10. 3201/eid2512.191070.

50. Kizu J, Neuman C, Le Grand L, Liu W. Discovery of Cocirculating Ross River virus and Barmah Forest virus at Wide Bay Military Training Area, Northeastern Australia. J Am Mosq Control Assoc. 2019;35:220-3. https://doi.org/10.2987/196821.1 .

51. Koolhof IS, Gibney KB, Bettiol S, Charleston M, Wiethoelter A, Arnold AL, et al. The forecasting of dynamical Ross River virus outbreaks: Victoria, Australia. Epidemics. 2020;30:100377. https://doi.org/10.1016/j.epidem.2019.100377.

52. Aubry M, Kama M, Vanhomwegen J, Teissier A, MariteragiHelle T, Hue S, et al. Ross river virus antibody prevalence, Fiji Islands, 2013-2015. Emerg Infect Dis. 2019;25:827-30. https:// doi.org/10.3201/eid2504.180694.

53. Shanks GD. Could Ross River virus be the next Zika? J Travel Med. 2019;26:taz003. https://doi.org/10.1093/jtm/taz003.

54. Tall JA, Gatton ML, Achee N. Flooding and Arboviral disease: predicting Ross River virus disease outbreaks across Inland Regions of South-Eastern Australia. J Med Entomol. 2020;57: 241-51. https://doi.org/10.1093/jme/tjz120.

55. Yu W, Dale P, Turner L, Tong S. Projecting the impact of climate change on the transmission of Ross River virus: methodological challenges and research needs. Epidemiol Infect. 2014;142:201323. https://doi.org/10.1017/S0950268814000399.

56. Srivastava P, Kumar A, Hasan A, Mehta D, Kumar R, Sharma C, et al. Disease resolution in Chikungunya - what decides the outcome? Front Immunol. 2020;11:695. https://doi.org/10.3389/ fimmu.2020.00695.

57. Hiroki CH, Toller-Kawahisa JE, Fumagalli MJ, et al. Neutrophil extracellular traps effectively control acute Chikungunya virus infection. Front Immunol. 2020;10:1-11. https://doi.org/10. 3389/fimmu.2019.03108 This article describes the role of neutrophil extracellcular traps in control of acute CHIKV infection.
58. Schwartz O, Albert ML. Biology and pathogenesis of chikungunya virus. Nat Rev Microbiol. 2010;8:491-500. https:// doi.org/10.1038/nrmicro2368.

59. Müller M, Slivinski N, Todd EJAA, Khalid H, Li R, Karwatka M, et al. Chikungunya virus requires cellular chloride channels for efficient genome replication. PLoS Negl Trop Dis. 2019;13:119. https://doi.org/10.1371/journal.pntd.0007703.

60. Sourisseau M, Schilte C, Casartelli N, Trouillet C, GuivelBenhassine F, Rudnicka D, et al. Characterization of reemerging chikungunya virus. PLoS Pathog. 2007;3:0804-17. https://doi. org/10.1371/journal.ppat.0030089.

61. Matusali G, Colavita F, Bordi L, Lalle E, Ippolito G, Capobianchi M, et al. Tropism of the chikungunya virus. Viruses. 2019;11. https://doi.org/10.3390/v11020175.

62. Vairo F, Haider N, Kock R, Ntoumi F, Ippolito G, Zumla A. Chikungunya: epidemiology, pathogenesis, clinical features, management, and prevention. Infect Dis Clin N Am. 2019;33:100325. https://doi.org/10.1016/j.idc.2019.08.006.

63. Cavalheiro MG, Da Costa LS, Campos HS, et al. Macrophages as target cells for Mayaro virus infection: involvement of reactive oxygen species in the inflammatory response during virus replication. An Acad Bras Cienc. 2016;88:1485-99. https://doi.org/10. 1590/0001-3765201620150685.

64. Schnierle BS. Cellular attachment and entry factors for chikungunya virus. Viruses. 2019;11:1-9. https://doi.org/10. 3390/v11111078.

65.• Zhang R, Kim AS, Fox JM, et al. Mxra8 is a receptor for multiple arthritogenic alphaviruses. Nature. 2018;557:570-4. https://doi.org/10.1038/s41586-018-0121-3 This article describes the role of the newly discovered Mxra8 receptor and its role in CHIKV pathogenesis.

66.•• Song H, Zhao Z, Chai Y, et al. Molecular basis of arthritogenic alphavirus receptor MXRA8 binding to Chikungunya virus envelope protein. Cell. 2019;177:1714-1724.e12. https://doi.org/ 10.1016/j.cell.2019.04.008 This article describes the biochemal structure of the Mxra8 receptor and its role in pathogenesis.

67. Kim AS, Zimmerman O, Fox JM, et al. An evolutionary insertion in the Mxra8 receptor-binding site confers resistance to alphavirus infection and pathogenesis. Cell Host Microbe. 2020;27:428 440.e9. https://doi.org/10.1016/j.chom.2020.01.008.

68. Young AR, Locke MC, Cook LE, Hiller BE, Zhang R, Hedberg ML, et al. Dermal and muscle fibroblasts and skeletal myofibers survive chikungunya virus infection and harbor persistent RNA. PLoS Pathog. 2019;15:e1007993. https://doi.org/10.1371/journal. ppat.1007993.

69. Goupil BA, Mores CN. A review of chikungunya virus-induced arthralgia: clinical manifestations, therapeutics, and pathogenesis. Open Rheumatol J. 2019;10:129-40. https://doi.org/10.2174/ 1874312901610010129.

70. Silva LA, Dermody TS. Chikungunya virus: epidemiology, replication, disease mechanisms, and prospective intervention strategies. J Clin Invest. 2017;127:737-49. https://doi.org/10.1172/ JCI84417.

71. Basore K, Kim AS, Nelson CA, et al. HHS Public Access 2020;177:1725-1737. https://doi.org/10.1016/j.cell.2019.04.006. Cryo-EM

72. Baxter VK, Heise MT. Immunopathogenesis of alphaviruses. In: Advances in Virus Research, 1st ed. Elsevier Inc., pp 315-382

73. Cook LE, Locke MC, Young AR, Monte K, Hedberg ML, Shimak RM, et al. Distinct roles of interferon alpha and beta in controlling chikungunya virus replication and modulating neutrophil-mediated inflammation. J Virol. 2019;94:e00841-19. https://doi.org/10.1128/JVI.00841-19.

74. Teng T-S, Kam Y-W, Lee B, Hapuarachchi HC, Wimal A, Ng $\mathrm{LC}$, et al. A systematic meta-analysis of immune signatures in 
patients with acute Chikungunya virus infection. J Infect Dis. 2015;211:1925-35. https://doi.org/10.1093/infdis/jiv049.

75. Hoarau J-J, Gay F, Pellé O, Samri A, Jaffar-Bandjee MC, Gasque $\mathrm{P}$, et al. Identical strength of the $\mathrm{T}$ cell responses against $\mathrm{E} 2$, $\mathrm{nsP} 1$ and Capsid CHIKV proteins in recovered and chronic patients after the epidemics of 2005-2006 in La Reunion island. PLoS One. 2013;8:e84695. https://doi.org/10.1371/journal.pone. 0084695.

76. Kak G, Raza M, Tiwari BK. Interferon-gamma (IFN- $\gamma$ ): exploring its implications in infectious diseases. Biomol Concepts. 2018;9: 64-79. https://doi.org/10.1515/bmc-2018-0007.

77. Ninla-aesong P, Mitarnun W, Noipha K. Proinflammatory cytokines and chemokines as biomarkers of persistent arthralgia and severe disease after Chikungunya virus infection: a 5-year followup study in Southern Thailand. Viral Immunol. 2019;32:442-52. https://doi.org/10.1089/vim.2019.0064.

78. Teo T-H, Lum F-M, Claser C, Lulla V, Lulla A, Merits A, et al. A pathogenic role for $\mathrm{CD} 4+\mathrm{T}$ cells during Chikungunya virus infection in mice. J Immunol. 2013;190:259-69. https://doi.org/10. 4049/jimmunol.1202177.

79. Thanapati S, Ganu M, Giri P, Kulkarni S, Sharma M, Babar P, et al. Impaired NK cell functionality and increased TNF- $\alpha$ production as biomarkers of chronic chikungunya arthritis and rheumatoid arthritis. Hum Immunol. 2017;78:370-4. https://doi.org/ 10.1016/j.humimm.2017.02.006.

80. Nayak TK, Mamidi P, Sahoo SS, Kumar PS, Mahish C, Chatterjee $\mathrm{S}$, et al. P38 and JNK mitogen-activated protein kinases interact with Chikungunya virus non-structural protein-2 and regulate TNF induction during viral infection in macrophages. Front Immunol. 2019;10:786. https://doi.org/10.3389/fimmu.2019. 00786 .

81. Kelvin AA, Banner D, Silvi G, Moro ML, Spataro N, Gaibani P, et al. Inflammatory cytokine expression is associated with chikungunya virus resolution and symptom severity. PLoS Negl Trop Dis. 2011;5:e1279. https://doi.org/10.1371/journal.pntd. 0001279.

82. Deng J, Yu X-Q, Wang P-H. Inflammasome activation and Th17 responses. Mol Immunol. 2019;107:142-64. https://doi.org/10. 1016/j.molimm.2018.12.024.

83. Tanaka T, Narazaki M, Kishimoto T. IL-6 in inflammation, immunity, and disease. Cold Spring Harb Perspect Biol. 2014;6: a016295. https://doi.org/10.1101/cshperspect.a016295.

84. Sepúlveda-Delgado J, Vera-Lastra OL, Trujillo-Murillo K, Canseco-Ávila LM, Sánchez-González RA, Gómez-Cruz O, et al. Inflammatory biomarkers, disease activity index, and selfreported disability may be predictors of chronic arthritis after chikungunya infection: brief report. Clin Rheumatol. 2017;36: 695-9. https://doi.org/10.1007/s10067-016-3419-2.

85. Chow A, Her Z, Ong EKS, Chen JM, Dimatatac F, Kwek DJC, et al. Persistent arthralgia induced by chikungunya virus infection is associated with interleukin-6 and granulocyte macrophage colony-stimulating factor. J Infect Dis. 2011;203:149-57. https:// doi.org/10.1093/infdis/jiq042.

86. Chaaithanya IK, Muruganandam N, Sundaram SG, Kawalekar O, Sugunan AP, Manimunda SP, et al. Role of proinflammatory cytokines and chemokines in chronic arthropathy in CHIKV infection. Viral Immunol. 2011;24:265-71. https://doi.org/10.1089/ vim.2010.0123

87. Lohachanakul J, Phuklia W, Thannagith M, Thonsakulprasert T, Ubol S. High concentrations of circulating interleukin-6 and monocyte chemotactic protein-1 with low concentrations of interleukin-8 were associated with severe chikungunya fever during the 2009-2010 outbreak in Thailand. Microbiol Immunol. 2012;56:134-8. https:// doi.org/10.1111/j.1348-0421.2011.00417.x.
88. Rojas JM, Avia M, Martín V, Sevilla N. IL-10: a multifunctional cytokine in viral infections. J Immunol Res. 2017;2017:1-14. https://doi.org/10.1155/2017/6104054.

89. Poo YS, Nakaya H, Gardner J, Larcher T, Schroder WA, le TT, et al. CCR2 deficiency promotes exacerbated chronic erosive neutrophil-dominated Chikungunya virus arthritis. J Virol. 2014;88:6862-72. https://doi.org/10.1128/JVI.03364-13.

90. Hoarau J-J, Jaffar Bandjee M-C, Krejbich Trotot P, Das T, Li-PatYuen G, Dassa B, et al. Persistent chronic inflammation and infection by Chikungunya arthritogenic alphavirus in spite of a robust host immune response. J Immunol. 2010;184:5914-27. https://doi.org/10.4049/jimmunol.0900255.

91. Chirathaworn C, Chansaenroj J, Poovorawan Y. Cytokines and chemokines in Chikungunya virus infection: protection or induction of pathology. Pathogens. 2020;9:415. https://doi.org/10.3390/ pathogens9060415.

92. Burrack KS, Tan JJL, McCarthy MK, et al. Myeloid cell Arg1 inhibits control of arthritogenic alphavirus infection by suppressing antiviral T cells. PLoS Pathog. 2015;11:1-27. https://doi.org/ 10.1371/journal.ppat.1005191.

93. Broeckel RM, Haese N, Ando T, Dmitriev I, Kreklywich CN, Powers $\mathrm{J}$, et al. Vaccine-induced skewing of $\mathrm{T}$ cell responses protects against chikungunya virus disease. Front Immunol. 2019;10:2563. https://doi.org/10.3389/fimmu.2019.02563.

94. Stoermer KA, Burrack A, Oko L, Montgomery SA, Borst LB, Gill $\mathrm{RG}$, et al. Genetic ablation of arginase 1 in macrophages and neutrophils enhances clearance of an arthritogenic alphavirus. J Immunol. 2012;189:4047-59. https://doi.org/10.4049/jimmunol. 1201240.

95. Lombardi Pereira AP, Suzukawa HT, do Nascimento AM, et al. An overview of the immune response and Arginase I on CHIKV immunopathogenesis. Microb Pathog. 2019;135:103581. https:// doi.org/10.1016/j.micpath.2019.103581 This article describes the role of arginase 1 and its association with macrophages during CHIKV infection.

96. Torres-Ruesta A, Teo TH, Chan YH, Rénia L, Ng LFP. Pathogenic Th1 responses in CHIKV-induced inflammation and their modulation upon Plasmodium parasites co-infection. Immunol Rev. 2020;294:80-91. https://doi.org/10.1111/imr. 12825.

97. Paixão ES, Rodrigues LC, da Conceição Costa NM, et al. Chikungunya chronic disease: a systematic review and meta-analysis. Trans R Soc Trop Med Hyg. 2018;112:301-16. https://doi. org/10.1093/trstmh/try063.

98. Castro-Domínguez F, Salman-Monte TC, Ojeda F, et al. Chikungunya-related erosive arthritis: case report and literature review. Reumatol Clínica (English Ed). 2019;15:e119-21. https://doi.org/10.1016/j.reumae.2018.11.009.

99.• Chang AY, Encinales L, Porras A, et al. Frequency of chronic joint pain following Chikungunya virus infection: a colombian cohort study. Arthritis Rheum. 2018;70:578-84. https://doi.org/ 10.1002/art.40384 This article describes a cohort of $\mathbf{3 8}$ patients from Colombia in which there were no detectable viral proteins or RNA in synovial fluid 22 months post infection.

100. Chang AY, Martins KAO, Encinales L, Reid SP, Acuña M, Encinales $\mathrm{C}$, et al. Chikungunya arthritis mechanisms in the Americas. Arthritis Rheum. 2018;70:585-93. https://doi.org/10. 1002/art.40383.

101.• Tritsch SR, Encinales L, Pacheco N, et al. Chronic joint pain 3 years after Chikungunya virus infection largely characterized by relapsing-remitting symptoms. J Rheumatol. 2019;47(8):126774. https://doi.org/10.3899/jrheum.190162 jrheum.190162. This article describes persistent joint pain and stiffness in patients 40 months post viral CHIKV infection. 
102. Venigalla SSK, Premakumar S, Janakiraman V. A possible role for autoimmunity through molecular mimicry in alphavirus mediated arthritis. Sci Rep. 2020;10:1-12. https://doi.org/10.1038/ s41598-019-55730-6.

103. Bautista-Vargas M, Puerta-Sarmiento G, Cañas CA. Characteristics of Chikungunya virus infection in patients with established rheumatoid arthritis. Clin Rheumatol. 2020. https:// doi.org/10.1007/s10067-020-05198-x.

104. Kikuti M, Tauro LB, Moreira PSS, Nascimento LCJ, Portilho MM, Soares GC, et al. Evaluation of two commercially available chikungunya virus IgM enzyme-linked immunoassays (ELISA) in a setting of concomitant transmission of chikungunya, dengue and Zika viruses. Int J Infect Dis. 2020;91:38-43. https://doi.org/10. 1016/j.ijid.2019.11.001.

105. Waggoner J, Heath CJ, Ndenga B, et al. Development of a realtime reverse transcription polymerase chain reaction for O'nyongnyong virus and evaluation with clinical and mosquito specimens from Kenya. Am J Trop Med Hyg. 2017;97:121-4. https://doi. org/10.4269/ajtmh.17-0027.

106. Poon AN, Simon GL, Chang AY. Treatment of chronic chikungunya with methotrexate. JCR J Clin Rheumatol. 2019;Publish Ah:; 10.1097/RHU.0000000000000998.

107. Anderson J, Caplan L, Yazdany J, Robbins ML, Neogi T, Michaud K, et al. Rheumatoid arthritis disease activity measures: American college of rheumatology recommendations for use in clinical practice. Arthritis Care Res. 2012;64:640-7. https://doi. org/10.1002/acr.21649.

108. Watson H, Tritsch SR, Encinales L, Cadena A, Cure C, Ramirez AP, et al. Stiffness, pain, and joint counts in chronic chikungunya disease: relevance to disability and quality of life. Clin Rheumatol. 2020;39:1679-86. https://doi.org/10.1007/s10067-019-04919-1.

109. de Brito CAA, von Sohsten AKA, de Sá Leitão CC, et al. Pharmacologic management of pain in patients with Chikungunya: a guideline. Rev Soc Bras Med Trop. 2016;49: 668-79. https://doi.org/10.1590/0037-8682-0279-2016.

110. Simon F, Javelle E, Cabie A, Bouquillard E, Troisgros O, Gentile $\mathrm{G}$, et al. French guidelines for the management of chikungunya (acute and persistent presentations). November 2014. Médecine Mal Infect. 2015;45:243-63. https://doi.org/10.1016/j.medmal. 2015.05.007.

111. Marques CDL, Duarte ALBP, Ranzolin A, et al. Recommendations of the Brazilian Society of Rheumatology for the diagnosis and treatment of chikungunya fever. Part $2-$ Treatment. Rev Bras Reumatol (English Ed). 2017;57:438-51. https://doi.org/10.1016/j.rbre.2017.06.004.

112. Amaral JK, Sutaria R, Schoen RT. Treatment of chronic Chikungunya arthritis with methotrexate: a systematic review. Arthritis Care Res. 2018;70:1501-8. https://doi.org/10.1002/acr. 23519.

113. Bedoui Y, Guillot X, Sélambarom J, et al. Methotrexate an old drug with new tricks. Int J Mol Sci. 2019;20:5023. https://doi.org/ 10.3390/ijms20205023 This article describes the potential of using methotrexate in patients with persistent joint symptoms following alphaviral infection.

114. Savarino A, Cauda R, Cassone A. On the use of chloroquine for chikungunya. Lancet Infect Dis. 2007;7:633. https://doi.org/10. 1016/S1473-3099(07)70217-7.

115. Roques P, Thiberville S-D, Dupuis-Maguiraga L, Lum FM, Labadie K, Martinon F, et al. Paradoxical effect of chloroquine treatment in enhancing Chikungunya virus infection. Viruses. 2018;10:268. https://doi.org/10.3390/v10050268.

116. Padmakumar B, Jayan JB, Menon RM, et al. Comparative evaluation of four therapeutic regimes in chikungunya arthritis: a prospective randomized parallel-group study. Indian J Rheumatol. 2009;4:94-101. https://doi.org/10.1016/S0973-3698(10)60189-6.
117. Ganu MA, Ganu AS. Post-chikungunya chronic arthritis-our experience with DMARDs over two year follow up. J Assoc Physicians India. 2011;59:83-6.

118. Arroyo-Ávila M, Vilá LM. Rheumatic manifestations in patients with Chikungunya infection. P R Health Sci J. 2015;34:71-7.

119. Vane JR, Botting RM. Mechanism of action of nonsteroidal antiinflammatory drugs. Am J Med. 1998;104:2S-8S. https://doi.org/ 10.1016/S0002-9343(97)00203-9.

120. Chen C. COX-2's new role in inflammation. Nat Chem Biol. 2010;6:401-2. https://doi.org/10.1038/nchembio.375.

121. Suhrbier A, La Linn M. Clinical and pathologic aspects of arthritis due to Ross River virus and other alphaviruses. Curr Opin Rheumatol. 2004;16:374-9. https://doi.org/10.1097/01.bor. 0000130537.76808.26.

122. Mylonas AD, Brown AM, Carthew TL, Purdie DM, Pandeya N, Collins LG, et al. Natural history of Ross River virus-induced epidemic polyarthritis. Med J Aust. 2002;177:356-60. https:// doi.org/10.5694/j.1326-5377.2002.tb04837.x.

123. Jaffar-Bandjee MC, Ramful D, Gauzere BA, Hoarau JJ, KrejbichTrotot $\mathrm{P}$, Robin S, et al. Emergence and clinical insights into the pathology of Chikungunya virus infection. Expert Rev Anti-Infect Ther. 2010;8:987-96. https://doi.org/10.1586/eri.10.92.

124. Suhrbier A, Jaffar-Bandjee MC, Gasque P. Arthritogenic alphaviruses-an overview. Nat Rev Rheumatol. 2012;8:420-9. https://doi.org/10.1038/nrrheum.2012.64.

125. Lopes Marques CD, Ranzolin A, Cavalcanti NG, Branco Pinto Duarte AL. Arboviruses related with chronic musculoskeletal symptoms. Best Pract Res Clin Rheumatol. 2020;34:101502. https://doi.org/10.1016/j.berh.2020.101502.

126. Mylonas AD, Harley D, Purdie DM, Pandeya N, Vecchio PC, Farmer JF, et al. Corticosteroid therapy in an alphaviral arthritis. JCR J Clin Rheumatol. 2004;10:326-30. https://doi.org/10.1097/ 01.rhu.0000147052.11190.36.

127. Cronstein BN, Aune TM. Methotrexate and its mechanisms of action in inflammatory arthritis. Nat Rev Rheumatol. 2020;16: 145-54. https://doi.org/10.1038/s41584-020-0373-9.

128. Martinez GP, Zabaleta ME, Di Giulio C, et al. The role of chloroquine and hydroxychloroquine in immune regulation and diseases. Curr Pharm Des. 2020;26:4467-85. https://doi.org/10.2174/ 1381612826666200707132920.

129. Schrezenmeier E, Dörner T. Mechanisms of action of hydroxychloroquine and chloroquine: implications for rheumatology. Nat Rev Rheumatol. 2020;16:155-66. https://doi.org/10. 1038/s41584-020-0372-x.

130. Rodrigo C, Fernando SD, Rajapakse S. Clinical evidence for repurposing chloroquine and hydroxychloroquine as antiviral agents: a systematic review. Clin Microbiol Infect. 2020;26: 979-87. https://doi.org/10.1016/j.cmi.2020.05.016.

131. Roques P, Thiberville SD, Dupuis-Maguiraga L, Lum FM, Labadie K, Martinon F, et al. Paradoxical effect of chloroquine treatment in enhancing chikungunya virus infection. Viruses. 2018;10:1-18. https://doi.org/10.3390/v10050268.

132. Herrero LJ, Foo S-S, Sheng K-C, Chen W, Forwood MR, Bucala $\mathrm{R}$, et al. Pentosan polysulfate: a novel glycosaminoglycan-like molecule for effective treatment of alphavirus-induced cartilage destruction and inflammatory disease. J Virol. 2015;89:8063-76. https://doi.org/10.1128/JVI.00224-15.

133. Ghosh P, Edelman J, March L, Smith M. Effects of pentosan polysulfate in osteoarthritis of the knee: a randomized, doubleblind, placebo-controlled pilot study. Curr Ther Res. 2005;66: 552-71. https://doi.org/10.1016/j.curtheres.2005.12.012.

134. Kumagai K, Shirabe S, Miyata N, Murata M, Yamauchi A, Kataoka $\mathrm{Y}$, et al. Sodium pentosan polysulfate resulted in cartilage improvement in knee osteoarthritis - an open clinical trial. BMC Clin Pharmacol. 2010;10:7. https://doi.org/10.1186/1472-6904-10-7. 
135. Blettery M, Brunier L, Polomat K, Moinet F, Deligny C, Arfi S, et al. Brief report: management of chronic post-Chikungunya rheumatic disease: the Martinican experience. Arthritis Rheum. 2016;68:2817-24. https://doi.org/10.1002/art.39775.

136. Udalova I, Nanchahal J, Feldmann M. Anti-TNF therapy. Microbiol Spectr. 2016;4:1-11. https://doi.org/10.1128/ microbiolspec MCHD-0022-2015.Correspondence.

137. Crunkhorn S. Targeting T cells to treat Chikungunya virus infections. Nat Rev Drug Discov. 2017;16:237. https://doi.org/10. 1038/nrd.2017.49.

138. Teo T-H, Chan Y-H, Lee WWL, et al. Fingolimod treatment abrogates chikungunya virus-induced arthralgia. Sci Transl Med. 2017;9:eaal1333. https://doi.org/10.1126/scitranslmed. aal1333 This article describes the use of fingolimod to block $T$ cell escape from lymph nodes as a way to decrease inflammation.

139. Miner JJ, Cook LE, Hong JP, et al. Therapy with CTLA4-Ig and an antiviral monoclonal antibody controls chikungunya virus arthritis. Sci Transl Med. 2017;9:eaah3438. https://doi.org/10. 1126/scitranslmed.aah3438 This article describes the use of CTLA4-Ig in a mouse model to eliminate alphavirus associated inflammatory symptoms.

140. Chen W, Foo S-S, Taylor A, Lulla A, Merits A, Hueston L, et al. Bindarit, an inhibitor of monocyte chemotactic protein synthesis, protects against bone loss induced by chikungunya virus infection. J Virol. 2015;89:581-93. https://doi.org/10.1128/jvi.02034-14.

141. Rulli NE, Guglielmotti A, Mangano G, Rolph MS, Apicella C, Zaid A, et al. Amelioration of alphavirus-induced arthritis and myositis in a mouse model by treatment with bindarit, an inhibitor of monocyte chemotactic proteins. Arthritis Rheum. 2009;60: 2513-23. https://doi.org/10.1002/art.24682.

142. Hodge JA, Kawabata TT, Krishnaswami S, et al. The mechanism of action of tofacitinib - an oral Janus kinase inhibitor for the treatment of rheumatoid arthritis. Clin Exp Rheumatol. 34:318-28.

143. McHugh J. Potential therapies for chikungunya arthritis. Nat Rev Rheumatol. 2017;13:196. https://doi.org/10.1038/nrrheum.2017.21.

144. Powell LA, Miller A, Fox JM, Kose N, Klose T, Kim AS, et al. Human mAbs broadly protect against arthritogenic alphaviruses by recognizing conserved elements of the Mxra8 receptor-binding site. Cell Host Microbe. 2020;28(5):699-711.e7. 1-13. https://doi. org/10.1016/j.chom.2020.07.008.

145. Mostafavi H, Abeyratne E, Zaid A, Taylor A. Arthritogenic alphavirus-induced immunopathology and targeting host inflammation as a therapeutic strategy for alphaviral disease. Viruses. 2019;11:290. https://doi.org/10.3390/v11030290.

146. Roy E, Byrareddy SN, Reid SP. Role of microRNAs in bone pathology during Chikungunya virus infection. Viruses. 2020;12:1207. https://doi.org/10.3390/v12111207.

147. Jing D, Hao J, Shen Y, Tang G, Li ML, Huang SH, et al. The role of microRNAs in bone remodeling. Int J Oral Sci. 2015;7:131-43. https://doi.org/10.1038/ijos.2015.22.

148. Chen GL, Coates EE, Plummer SH, Carter CA, Berkowitz N, Conan-Cibotti M, et al. Effect of a Chikungunya virus-like particle vaccine on safety and tolerability outcomes. JAMA. 2020;323: 1369. https://doi.org/10.1001/jama.2020.2477.

149. Ramsauer K, Reisinger E, Firbas C, Wiedermann-Schmidt U, Beubler E, Pfeiffer A, et al. Phase 2 clinical results: Chikungunya vaccine based on measles vector (MV-CHIK) induces humoral and cellular responses in the presence of preexisting anti measles immunity. Int J Infect Dis. 2019;79:118. https://doi.org/10.1016/j.ijid.2018.11.291.

150. Valneva Austria GmbH. A multicenter, randomized, placebo-controlled, double-blinded pivotal study to evaluate safety and immunogenicity of a live-attenuated Chikungunya virus vaccine candidate in adults aged 18 years and above. In: Clin. Identifier NCT04546724

151. Schrauf S, Tschismarov R, Tauber E, Ramsauer K. Current efforts in the development of vaccines for the prevention of Zika and Chikungunya virus infections. Front Immunol. 2020;11:592. https://doi.org/10.3389/fimmu.2020.00592 This article summarizes all the current ongoing vaccine trials for CHIKV and Zika virus.

Publisher's Note Springer Nature remains neutral with regard to jurisdictional claims in published maps and institutional affiliations. 